\title{
Survival and proteolytic capacity of probiotics in a fermented milk enriched with agave juice and stored in refrigeration
}

\author{
Judith JAIMEZ-ORDAZ1 ${ }^{1}$, Xóchitl MARTÍNEZ-RAMÍREZ ${ }^{1}$, Alma Elizabeth CRUZ-GUERRERO², \\ Elizabeth CONTRERAS-LÓPEZ ${ }^{1}$, Alexis AYALA-NIÑO ${ }^{1}$, Javier CASTRO-ROSAS ${ }^{1}$, \\ Luis Guillermo GONZÁLEZ-OLIVARES ${ }^{1 *}$
}

\begin{abstract}
In this study, the survival and proteolysis of lactic acid bacteria Lactobacillus casei Shirota and Lactobacillus rhamnosus GG were measured in fermented milks enriched with agave juice and inulin. Fermentations were terminated at $\mathrm{pH} 4.5$ and stored for 21 days at $4{ }^{\circ} \mathrm{C}$. Survival was determined by viable count in MRS-agar. The production of free amino groups was performed by the TNBS method and peptide separation was performed by SDS-PAGE. During fermentation, $\mathrm{pH}$ decreased faster in milk with agave juice than with inulin. There was no significant difference in the concentration of free amino groups $(0.632 \pm 0.007$ and $0.627 \pm 0.007 \mathrm{mg} / \mathrm{L})$ between the two fermentation systems for any microorganism. The concentration of lactic acid bacteria in the presence of agave juice was higher than the recommended concentration for probiotic foods (7.59 $\log \mathrm{CFU} / \mathrm{mL}$ for L. rhamnosus GG and $8.26 \log \mathrm{CFU} / \mathrm{mL}$ for L. casei Shirota). The production of free amino groups and peptides of low molecular weight continued in refrigeration and was higher in systems with agave juice. This could represent a proteolytic activation in the presence of this carbon source. The results showed that agave juice might be a functional ingredient with prebiotic character in symbiotic systems.
\end{abstract}

Keywords: lactic acid bacteria; fermented milk; agave juice; inulin; proteolysis; prebiotic.

Practical Application: diversify prebiotic sources and increase survival and proteolytic capacity of probiotics.

\section{Introduction}

Fermented milks are an excellent vehicle for the inclusion of functional ingredients of dairy or non-dairy origin, such as probiotic bacteria, prebiotic carbohydrates, dietary fiber, and antioxidant compounds, among others. Lactic bacteria contribute to the bacteriological safety of the product and confer it a feature series from a sensorial, technological and nutritional point of view (Santillán-Urquiza et al., 2014; Holck et al., 2017). Beneficial properties of fermented milks can be attributed to the microorganisms and the different products released during the fermentation process (Leroy \& De Vuyst, 2004; Marco et al., 2017).

The proteolytic capacity of lactic bacteria plays a very important role during milk fermentation, mainly in the fractionation of proteins for conversion of peptides to free amino acids. Peptides that are not converted to free amino acids may be bioactive. Some of them act by binding to certain receptors, others are enzymes inhibitors, others regulate intestinal absorption, etc. (Ramchandran \& Shah, 2008).

Probiotics have been defined as living organisms, which, when ingested, beneficially affect the host by improving intestinal balance (Sánchez et al., 2017; Sebastián-Domingo, 2017). By modifying the intestinal microflora, probiotics directly and indirectly influence health status through the production of vitamins and short-chain fatty acids, degradation of undigested food substances, stimulation of immune response and protection against enteropathogenic microorganisms (Senok et al., 2005; Holck et al., 2017). A wide variety of species and genera can be considered as potential probiotics; however, commercially, lactic acid bacteria (LAB) are the most important (Vasiljevic \& Shah, 2008). In accordance with the Scientific Association for Probiotics and Prebiotics the established probiotics amount to confer benefits is of $10^{9} \mathrm{CFU} / \mathrm{mL}$ (Hill et al., 2014). However, the viability of probiotic bacteria must be guaranteed to the consumer. Viability of probiotic bacteria and their relationship to the addition of prebiotics as a source of carbon, including inulin and fructooligosaccharides from different sources, have been studied (Palaria et al., 2011). Then, prebiotics are food ingredients that selectively stimulate the growth and/or activity of a limited number of bacteria (Marteau \& Boutron-Ruault, 2002). Many food components, especially oligosaccharides and polysaccharides (including dietary fiber), have been used as prebiotics (Heydari et al., 2018).

Agave juice is extracted from various agave species used to prepare "pulque" (a traditional Mexican alcoholic beverage). In this plant inulin is one of reserve polysaccharide, so agave juice naturally presents derivatives of this, which are known as

${ }^{1}$ Área Académica de Química, Universidad Autónoma del Estado de Hidalgo, Mineral de la Reforma, Hidalgo, México

${ }^{2}$ Departamento de Biotecnología, Universidad Autónoma Metropolitana, Iztapalapa, CDMX, México

*Corresponding author: lgonzales@uaeh.edu.mx 
fructooligosaccharides (FOS). These oligosaccharides are chains of 2-10 fructose units, with a terminal glucose unit. It has been found that these compounds have prebiotic potential, stimulating the selective growth of probiotic bacteria in the colon of the consumer (Jasso-Padilla et al., 2017). The aim of this work was to evaluate the effect of the agave juice addition as a prebiotic source in the probiotic viability and its proteolytic capacity during milk fermentation and refrigerated storage at $4{ }^{\circ} \mathrm{C}$.

\section{Materials and methods}

\subsection{Agave juice analysis}

Agave juice was obtained from the scraping of three agaves (Agave salmiana var. "Ayoteco") from Epazoyucan, Hidalgo (Mexico). It was pasteurized in autoclave at $90^{\circ} \mathrm{C}$ for 15 minutes. The carbohydrate concentration was determined by HPLC (Lab Alliance, Tokyo, Japan). A 7.8 x 300 mm RNO-oligosaccharide column (Phenomenex, Torrance CA) and a Light Scattering detector (Polymer Laboratories, Amherst, MA) were used. The elution medium was pre-degassed water $\left(\right.$ at $75^{\circ} \mathrm{C}$ ) at a flow rate of $0.3 \mathrm{~mL} / \mathrm{min}$. The run was carried out at a constant temperature of $75{ }^{\circ} \mathrm{C}$ and the detector was maintained at a misting temperature of $110^{\circ} \mathrm{C}$.

\subsection{Starter cultures}

Two strains of lactic acid bacteria were used: Lactobacillus casei Shirota and Lactobacillus rhamnosus GG obtained from the Laboratory of Food Biotechnology of the Universidad Autónoma Metropolitana campus Iztapalapa (Mexico). These were preserved on MRS agar in refrigeration. The inoculum was prepared by growing the strains in MRS broth at $37^{\circ} \mathrm{C}$ for 36 hours. Plate count of colony forming units per milliliter (UFC/mL) on MRS-agar was performed.

\subsection{Fermentation}

Fermentations were carried out in $10 \%(\mathrm{w} / \mathrm{v})$ skim milk powder (Dairy Gold) added with $2 \%$ agave juice or inulin ( $E$ NATURE', Mexico) and pasteurized at $90^{\circ} \mathrm{C}$ for 15 minutes in autoclave. They were inoculated in monoculture with $10^{6} \mathrm{CFU} / \mathrm{mL}$ and incubated at $37{ }^{\circ} \mathrm{C}$ for $24 \mathrm{~h}$. Samples were taken during the fermentation and the $\mathrm{pH}$ was determined. To separate the biomass and the high molecular weight proteins, the samples were centrifuged at $10000 \mathrm{rpm}$ at $4{ }^{\circ} \mathrm{C}$ for $10 \mathrm{~min}$ in an Eppendorf centrifuge. The supernatant was reserved and stored in freezing at $-14{ }^{\circ} \mathrm{C}$ for further analysis. At the end of the fermentation plate count on MRS-agar was performed.

\subsection{Storage in refrigeration}

Fermented milks with each microorganism were stored at $4{ }^{\circ} \mathrm{C}$ for 21 days and samples were taken at 7, 14 and 21 days which were analyzed later.

\subsection{Free amino groups determination}

The analysis of free amino groups was determined by the trinitrobenzylsulfonic acid method (TNBS) (González-Olivares et al., 2014) and the concentration was determined according to a glycine standard curve $(0.05-0.25 \mathrm{mg} / \mathrm{mL})$.

\subsection{Peptide separation by electrophoresis on polyacrylamide gel (SDS-PAGE)}

Denaturing electrophoresis was performed with an acrylamide concentration of $15 \%(\mathrm{w} / \mathrm{v})$. The molecular weight standard was the broad range (Bio-Rad, USA). The gels were dyed with Comassie G-250 (Bio-Rad, USA). The electrophoretic profiles were analyzed by the Image J program. Molecular weights were estimated.

\subsection{Statistical analysis of results}

All experiments were performed by triplicate and the experimental data were subjected to an analysis of variance (ANOVA), the means comparison was done by the Tuckey's method with a significance level of 0.05 . The program used for the analysis was NCSS-2007 (version: 07-1-15).

\section{Results and discussion}

\subsection{Carbohydrates concentration in agave juice}

In agave juice the total carbohydrate concentration was $3.2 \%(\mathrm{w} / \mathrm{v})$, with a higher concentration of fructose $(33.88 \%)$ and glucose (27.94\%) than of di- and poly- saccharides (sucrose 20.59\%; oligosaccharides 20\%). Willems \& Low (2012) after analyzing 19 samples, reported that fructose is the carbohydrate of higher concentration in agave juice from three regions of Mexico (Nayarit, Jalisco and Michoacán).

On the other hand, because of their complex structures with $\beta-(1-2)$ and $\beta-(2-6)$ bonds, it has been suggested that fructans present in the agave juice must be called agavins (Lopez et al., 2003).

\subsection{Fermentation}

The $\mathrm{pH}$ was measured during the fermentation. It was observed that milks inoculated with Lactobacillus casei Shirota or Lactobacillus rhamnosus $G G$, decreased its $\mathrm{pH}$ faster to 4.5 with the addition of agave juice (18 and 24 hours, respectively) than with inulin (34 and 36 hours, respectively).

The decrease of $\mathrm{pH}$ during the fermentation is influenced by the production of short chain organic acids which depends in the amount of available sugars (Corsetti et al., 1998; Lopez et al., 2003). It has been shown that the addition of inulin stimulates the metabolism of some LAB, probably due to the release of available sugars during its hydrolysis (Souza et al., 2012). A shorter time to reach a $\mathrm{pH}$ of 4.5 in the media added with agave juice, may mean that this has a greater amount of FOS which can be hydrolyzed into fermentable and available sugars, and simple sugars, that those present in inulin.

\subsection{Probiotic survival during storage in refrigeration}

No difference in L. casei Shirota growth was observed, in milk enriched with agave juice (Table 1). In fact, the viable count of $L$. casei Shirota in both milks (enriched with agave juice or inulin) was maintained at levels higher than those recommended $\left(1 \times 10^{6} \mathrm{CFU} / \mathrm{mL}\right)$ during refrigerated storage. In fermented milks with L. rhamnosus GG (Table 2), both milks showed no significant difference in the viable count during the 
Table 1. L. casei Shirota and L. rhamnosus GG survival during $4^{\circ} \mathrm{C}$ storage of fermented milks with agave juice (a) and inulin (b) addition.

\begin{tabular}{|c|c|c|c|c|}
\hline \multirow{3}{*}{ Week } & \multicolumn{4}{|c|}{$\log \mathrm{CFU} / \mathrm{mL}$} \\
\hline & \multicolumn{2}{|c|}{ L. casei Shirota } & \multicolumn{2}{|c|}{ L. rhamnosus GG } \\
\hline & $\mathrm{a}$ & $\mathrm{b}$ & $\mathrm{a}$ & $\mathrm{b}$ \\
\hline 0 & $8.28 \pm 0.07$ & $7.58 \pm 0.11$ & $8.50 \pm 0.06$ & $7.58 \pm 0.13$ \\
\hline 1 & $8.40 \pm 0.06$ & $7.59 \pm 0.01$ & $8.48 \pm 0.01$ & $7.65 \pm 0.21$ \\
\hline 2 & $8.29 \pm 0.03$ & $7.36 \pm 0.00$ & $8.40 \pm 0.05$ & $7.73 \pm 0.05$ \\
\hline 3 & $8.26 \pm 0.14$ & $7.60 \pm 0.33$ & $7.64 \pm 0.14^{\star}$ & $7.60 \pm 0.14$ \\
\hline
\end{tabular}

${ }^{*}$ Statistical differences $p \leq 0.05$.

Table 2. L. casei Shirota and L. rhamnosus GG free amino groups concentration during $4{ }^{\circ} \mathrm{C}$ storage of fermented milks with agave juice (a) and inulin (b) addition.

\begin{tabular}{|c|c|c|c|c|}
\hline \multirow{3}{*}{ Week } & \multicolumn{4}{|c|}{$\mathrm{mg} / \mathrm{L}$} \\
\hline & \multicolumn{2}{|c|}{ L. casei Shirota } & \multicolumn{2}{|c|}{ L. rhamnosus GG } \\
\hline & $\mathrm{a}$ & $\mathrm{b}$ & $\mathrm{a}$ & $\mathrm{b}$ \\
\hline 1 & $0.550 \pm 0.01$ & $0.42 \pm 0.01$ & $0.563 \pm 0.004$ & $0.424 \pm 0.007$ \\
\hline 2 & $0.62 \pm 0.01^{\star}$ & $0.42 \pm 0.01$ & $0.577 \pm 0.001$ & $0.442 \pm 0.001$ \\
\hline 3 & $0.55 \pm 0.01$ & $0.43 \pm 0.01$ & $0.586 \pm 0.001$ & $0.446 \pm 0.007$ \\
\hline
\end{tabular}

${ }^{\star}$ Statistical differences $p \leq 0.05$.

first two weeks of storage. Nevertheless, in the system with agave juice a significant decrease $(p \leq 0.05)$ ( 1 logarithmic cycle) was presented at the end of the study.

In accordance with storage studies at low temperatures, the survival of microorganisms can be determined by the relationship between the culture medium and the microorganism, so that the decrease in viability can vary up to $3 \log$ cycles in yogurts or fermented milks (Rybka \& Kailasapathy, 1995; Sadaghdar et al., 2012; Nematollahi et al., 2016). This means that the components of the medium can diffuse passively through the cells and interfere with the metabolic processes. That is why bacterial cellular wall plays an important role in cellular osmotic transport (Bozoglu et al., 1987). Nielsen et al. (2009) observed that in fermented milks stored in refrigeration $\left(5^{\circ} \mathrm{C}\right)$ for 6 days, the number of viable cells did not present significant difference even when the systems were not enriched with any prebiotic.

\subsection{Free amino groups during fermentation}

With the aim to monitor proteolysis during fermentation, samples were taken at 2, 4, 8, 12 and 24 hours. It was shown, that Lactobacillus casei Shirota has a greater proteolytic capacity, reaching a concentration of $0.64 \pm 0.02 \mathrm{mg} / \mathrm{L}$ of free amino groups at the end of the fermentation, no difference between the additions of inulin or agave juice was shown $(p \leq 0.05)$. While the milks inoculated with Lactobacillus rhamnosus GG, reached a concentration of $0.56 \mathrm{mg} / \mathrm{L}$ with the addition of agave juice and $0.42 \mathrm{mg} / \mathrm{L}$ with inulin.

This difference could be due to the ability of LAB to increase cell density in milk, being dependent of its proteolytic system, which in turn involves the progressive hydrolysis of caseins to polypeptides, peptides and amino acids (Guo et al., 2009; Griffiths \& Tellez, 2013). The differences in free amino groups concentration among the different species of lactobacilli are always dependent on their nutritional requirements and the proteolytic capacity of each species (Gasson \& de Vos, 1994).

Peptides production during fermentation is favored by different factors (Gobbetti et al., 2004). Within these factors the carbon source plays a preponderant role in the proteolytic activity. Many carbon sources used in probiotic studies are non-digestible fermentable carbohydrates with a variable number of monosaccharide residues. Some examples are lactulose, galacto and FOS and resistant starch. These prebiotics have been shown to influence the survival and metabolism of probiotic bacteria (Saarela et al., 2000; Adebola et al., 2014).

\subsection{Free amino group determination during refrigerated storage}

Fermented milks were sampled every 7 days during the refrigeration storage process at $4{ }^{\circ} \mathrm{C}$, since it has been reported that this is the time required to observe possible differences, due to the metabolism is decelerated (Donkor et al., 2007). In the analysis of free amino groups during refrigerated storage of milk inoculated with $L$. casei Shirota with agave juice addition, an increase in the second week of storage followed by a decrease in the final sampling was observed $(p \leq 0.05)$. While in the milk with inulin, the concentration remained constant until the end of the storage having the same behavior in milks inoculated with L. rhamnosus GG (Table 2).

It is known that the number of microorganisms generated during fermentation maintains a high activity of the proteases, however, during long periods of cooling these activity decreases but they are not entirely inactivated (Shi et al., 2014). As it can be observed, the increase in free amino groups concentration was slow compared to the fermentation process. This is because during cold storage, microorganisms use the amino acids released during proteolysis to survive and only perform cutting work 
when these amino acids are insufficient for their growth (Bu et al., 2010). Viability results confirmed the presence of microorganisms with the consequent metabolic activity. It was observed that even at low temperatures (in both inulin and agave juice fermented milks), and with any of the probiotic microorganisms tested, the minimum concentrations of microorganism recommended to provide health benefits were reached (Rybka \& Kailasapathy, 1995; Kechagia et al., 2013).

\subsection{Peptides produced during storage}

To separate the peptides produced during refrigerated storage, samples were taken at $0,7,14$ and 21 days of storage at $4^{\circ} \mathrm{C}$. In milk fermented by Lactobacillus casei Shirota and enriched with agave juice (Figure 1A), it was observed that the apparent concentration of low molecular weight peptides (below $6.5 \mathrm{kDa}$ ) during storage, increased significantly from week 1 to week 3 . Small peptides with molecular weights lower than $6 \mathrm{kDa}$ were observed. This range of molecular weights had previously been reported in the separation of peptides from commercial fermented milks (González-Olivares et al., 2011). On the other hand, in milk enriched with inulin (Figure 2B) no defined bands were observed in the range of 14.4 to $6.5 \mathrm{kDa}$ during all weeks of storage. Some peptides with low molecular weight appeared in the first or second refrigeration week and were maintained until the end of the study. However, an accumulation of low molecular weight peptides (below $6.5 \mathrm{kDa}$ ) was found at the end of the refrigerated storage. This accumulation coincided with the lower concentration of a molecular weight band at $12.3 \mathrm{kDa}$. Although peptides accumulated in the system with agave juice were of lower molecular weight than those of milk with inulin, showing a higher proteolytic capacity.

Analyzing Lactobacillus rhamnosus GG fermented milks, differences in the production of peptides were shown. In the fermented milk enriched with agave juice (Figure 2A), peptides of less than $6.5 \mathrm{kDa}$ were observed. These were generated at week 1 and were maintained throughout the study, which could indicate no degradation and accumulation of low molecular weight peptides. On the other hand, fermented milk enriched with inulin (Figure 2B), bands in molecular weights close to $6.5 \mathrm{kDa}$ were observed and maintained during refrigerated storage. Peptides with molecular weights between 6.5 and $7.3 \mathrm{kDa}$ showed accumulation during storage.

Results obtained in this investigation are relevant since it has been verified that in refrigerated storage, the accumulation of peptides of low molecular weight is related to biological activity, such as antimicrobial activity which are described with molecular weights less than $10 \mathrm{kDa}$ (Moreno-Montoro et al., 2017).

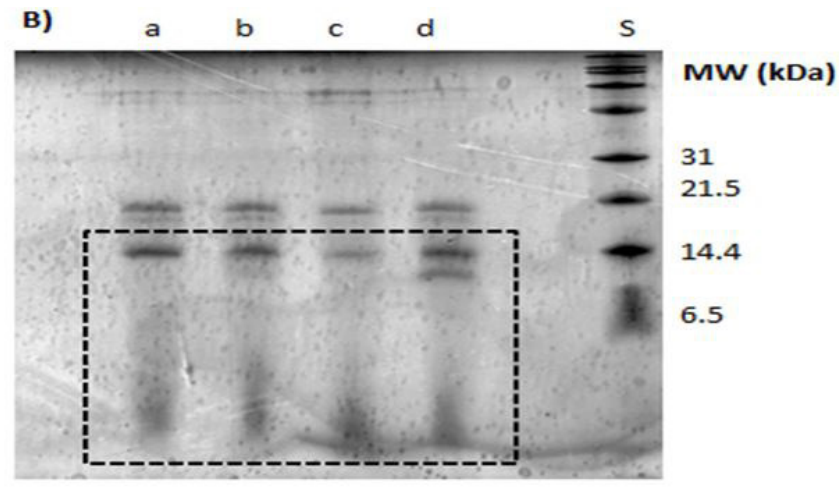

Figure 1. SDS-PAGE peptides separation from milk with agave juice (A) and inulin (B) fermented with Lactobacillus casei Shirota (a) day 0 of storage; (b) day 7 of storage; (c) day 14 of storage; (d) day 21 of storage; (S) standard.

A)

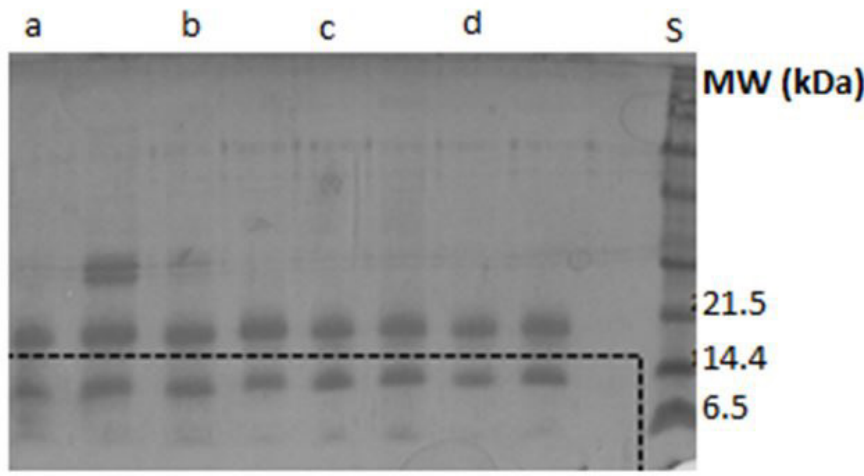

B)

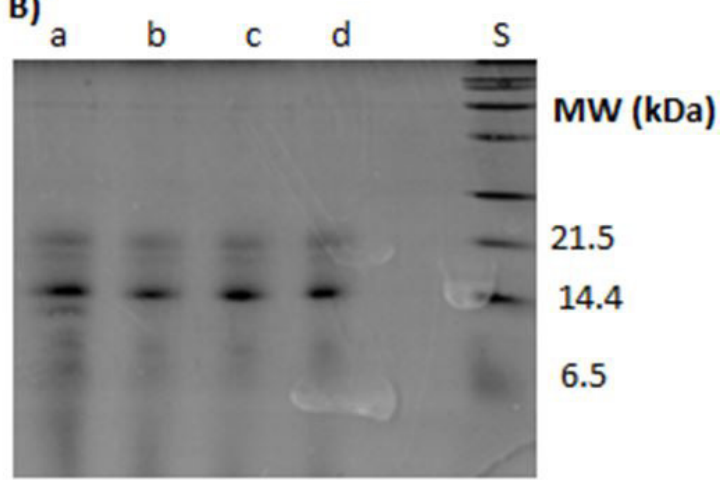

Figure 2. SDS-PAGE peptides separation from milk with agave juice (A) and inulin (B) fermented with Lactobacillus rhamnosus GG (a) day 0 of storage; (b) day 7 of storage; (c) day 14 of storage; (d) day 21 of storage; (S) standard. 
Milk proteins are considered the most important sources of bioactive peptides (Korhonen, 2009). In fermented milks, the protein hydrolysis is about 1 to $2 \%$ and this degradation is performed in $80 \%$ on milk caseins (Meisel \& Bockelmann, 1999). However, it has been observed that even when fermentation ends, the proteolytic activity continues in refrigerated storage (Nielsen et al., 2009). Vinderola et al. (2000) determined that, even when the optimum temperature of the enzymes of the LAB proteolytic system is between 32 and $37^{\circ} \mathrm{C}$, the system activity is not lost in refrigeration at $4{ }^{\circ} \mathrm{C}$, this agrees with the observed results in this study.

In addition, it has been found that biological activity (especially antihypertensive activity) generally increase in fermented milks stored at $4{ }^{\circ} \mathrm{C}$ for 28 days (Donkor et al., 2007; Moslehishad et al., 2013). Likewise, the ability to generate peptides during refrigerated storage has also been observed in commercial fermented milks, using different microorganisms (González-Olivares et al., 2011).

The release of peptides during the refrigerated storage process is associated with the proteolytic system of living bacteria and enzymes released after cell lysis (Nighswonger et al., 1996). The peptide release process follows a model proposed by Gasson \& de Vos (1994), which includes a cascade release process that begins with the primary hydrolysis of milk proteins. In this process, high molecular weight peptides are hydrolyzed to give intermediate molecular weight peptides and from these the production of low molecular weight peptides is achieved. Results obtained for fermented milks in this investigation are in accordance with the model proposed by these authors, since during the refrigerated storage the appearance and disappearance of peptides of high molecular weight and intermediate molecular weight were observed. At the same time, the accumulation of peptides was higher when they were of low molecular weight.

The most recent study demonstrates (Martinez-Gutierrez et al., 2017) that agave juice helps to increase probiotics concentration during fermentation process. However, any study is related with the refrigeration process and the changes in the proteolytic capacity of this kind of bacteria and it is not specified the relation with prebiotic effect over the proteolytic capacity of probiotics.

\section{Conclusions}

Agave juice promoted $\mathrm{pH}$ lowering in fermentation systems inoculated with probiotics promoting the survival of probiotic bacteria for at least during the first two weeks in refrigerated storage. Probiotic lactic acid bacteria produced a higher number of low molecular weight peptides in agave juice enriched milks, which are important because their probable bioactive action as result of the protein hydrolysis. This means that agave juice could influence the proteolytic activity of the lactic acid bacteria tested during fermentation and refrigerated storage, having a higher concentration of free amino groups. Finally, agave juice has high potential as a prebiotic agent for Lactobacillus casei Shirota and Lactobacillus rhamnosus GG in milk media. It allowed viable counts of probiotic bacteria, higher than the minimum recommended to provide beneficial effects to the consumer during refrigerated storage. A deeper study is necessary to identify peptides sequences and their possible bioactivity and it is also recommendable to make a comparison of agave juice with another carbon sources to amplify the discussion around of this probable functional ingredient.

\section{References}

Adebola, O. O., Corcoran, O., \& Morgan, W. A. (2014). Synbiotics: the impact of potential prebiotics inulin, lactulose and lactobionic acid in the survival and growth of lactobacilli probiotics. Journal of Functional Foods, 10, 75-84. http://dx.doi.org/10.1016/j.jff.2014.05.010.

Bozoglu, T. F., Özilgen, M., \& Bakir, U. (1987). Survival kinetics of lactic acid starter cultures during and after freeze drying. Enzyme and Microbial Technology, 9(9), 531-537. http://dx.doi.org/10.1016/01410229(87)90082-2.

Bu, G., Luo, Y., Zhang, Y., \& Chen, F. (2010). Effects of fermentation by lactic acid bacteria on the antigenicity of bovine whey proteins. Journal of the Science of Food and Agriculture, 90(12), 2015-2020. http://dx.doi.org/10.1002/jsfa.4046. PMid:20583192.

Corsetti, A., Gobbetti, M., Rossi, J., \& Damiani, P. (1998). Antimould activity of sourdough lactic acid bacteria: identification of a mixture of organic acids produced by Lactobacillus sanfrancisco CB1. Applied Microbiology and Biotechnology, 50(2), 253-256. http://dx.doi. org/10.1007/s002530051285. PMid:9763693.

Donkor, O. N., Henriksson, A., Singh, T. K., Vasiljevic, T., \& Shah, N. P. (2007). ACE- inhibitory activity of probiotic yoghurt. International Dairy Journal, 17(11), 1321-1331. http://dx.doi.org/10.1016/j. idairyj.2007.02.009.

Gasson, M. J., \& de Vos, W. M. (1994). The proteolytic system of lactic acid bacteria, genetics and biotechnology of lactic acid bacteria. M. J. Gasson \& W. M. Vos (Ed.), Genetics and biotechnology of lactic acid bacteria (pp. 169-210). USA: Blackie Academic y Proffessional an Imprint of Chapman y Hall. http://dx.doi.org/10.1007/978-94011-1340-3.

Gobbetti, M., Minervini, F., \& Rizzello, C. (2004). Angiotensin I-converting-enzyme -inhibitory and antimicrobial bioactive peptides. International Journal of Dairy Technology, 57(2), 173-188. http://dx.doi.org/10.1111/j.1471-0307.2004.00139.x.

González-Olivares, L. G., Jiménez-Guzmán, J., Cruz-Guerrero, A., Rodríguez-Serrano, G., Gómez-Ruiz, L., \& García-Garibay, M. (2011). Bioactive peptides released by lactic acid bacteria in commercial fermented milks. Revista Mexicana de Ingeniería Química, 10, 179188. http://dx.doi.org/10.1590/1678-457X.6415.

González-Olivares, L. G., López-Cuellar, Z. L., Añorve-Morga, J., Franco-Fernández, M. J., Castañeda-Ovando, A., Contreras-López, E., Jaimez-Ordaz, J., \& Rodríguez-Serrano, G. M. (2014). Viability and Proteolytic Capacity of Lactobacillus bulgaricus 2772 and Lactobacillus rhamnosus GG during cheese ripening. The Journal of Bioscience and Medicine, 2014, 7-12. http://dx.doi.org/10.4236/ jbm.2014.23002.

Griffiths, M. W., \& Tellez, A. M. (2013). Lactobacillus helveticus: the proteolytic system. Frontiers in Microbiology, 4(30), 1-9. http:// dx.doi.org/10.3389/fmicb.2013.00030.

Guo, Z., Wang, J., Yan, L., Chen, W., Liu, X., \& Zhang, H. (2009). In vitro comparison of probiotic properties of Lactobacillus casei Zhang, a potential new probiotic, with selected probiotic strains. Food Science and Technology (Campinas), 42, 1640-1646. http:// dx.doi.org/10.1016/j.lwt.2009.05.025.

Heydari, S., Amiri-Rigi, A., Ehsani, M. R., Mohammadifar, M. A., Khorshidian, N., Koushki, M. R., \& Mortazavian, A. M. (2018). Rheological behaviour, sensory properties and syneresis of probiotic 
yoghurt supplemented with various prebiotics. International Journal of Dairy Technology, 71, 175-184. http://dx.doi.org/10.1111/14710307.12491.

Hill, C., Guarner, F., Reid, G., Gibson, G. R., Merenstein, D. J., Pot, B., Morelli, L., Canani, R. B., Flint, H. J., Salminen, S., Calder, P. C., \& Sanders, M. E. (2014). The International Scientific Association for Probiotcs and Prebiotics consensus statement on the scope and appropriate use of the term probiotic. Nature Reviews. Gastroenterology \& Hepatology, 11(8), 506-514. http://dx.doi. org/10.1038/nrgastro.2014.66. PMid:24912386.

Holck, A., Axelsson, L., McLeod, A., Rode, T. M., \& Heir, E. (2017). Health and safety considerations of fermented sausages. Journal of Food Quality, 2017, 1-25. http://dx.doi.org/10.1155/2017/9753894.

Jasso-Padilla, I., Juárez-Flores, B., Alvarez-Fuentes, G., De la Cruz-Martínez, A., González-Ramírez, J., Moscosa-Santillán, M., González-Chávez, M., Oros-Ovalle, C., Prell, F., Czermak, P., \& Martinez-Gutierrez, F. (2017). Effect of prebiotics of Agave salmiana fed of healthy Wistar rats. Journal of the Science of Food and Agriculture, 97(2), 556-563. http://dx.doi.org/10.1002/jsfa.7764. PMid:27097820.

Kechagia, M., Basoulis, D., Konstantopoulou, S., Dimitriadi, D., Gyftopoulou, K., Skarmoutsou, N., \& Fakiri, E. M. (2013). Health benefits of probiotics: a review. Nutrition, 2013, 1-7. http://dx.doi. org/10.5402/2013/481651.

Korhonen, H. (2009). Milk-derived bioactive peptides: from science to applications. Journal of Functional Foods, 1(2), 177-187. http:// dx.doi.org/10.1016/j.jff.2009.01.007.

Leroy, F., \& De Vuyst, L. (2004). Lactic acid bacteria as functional starter cultures for the food fermentation industry. Trends in Food Science \& Technology, 15(2), 67-78. http://dx.doi.org/10.1016/j. tifs.2003.09.004.

Lopez, M. G., Mancilla-Margalli, N. A., \& Mendoza-Diaz, G. (2003). Molecular structures of fructans from Agave tequilana Weber var. azul. Journal of Agricultural and Food Chemistry, 51(27), 7835-7840. http://dx.doi.org/10.1021/jf030383v. PMid:14690361.

Marco, M. L., Heeney, D., Binda, S., Cifelli, C. J., Cotter, P. D., Foligné, B., Gänzle, M., Kort, R., Pasin, G., Pihlanto, A., Smid, E. J., \& Hutkins, R. (2017). Health benefits of fermented foods: microbiota and beyond. Current Opinion in Biotechnology, 44, 94-102. http:// dx.doi.org/10.1016/j.copbio.2016.11.010. PMid:27998788.

Marteau, P., \& Boutron-Ruault, M. C. (2002). Nutritional advantages of probiotics and prebiotics. British Journal of Nutrition, 87(Suppl 2), S153-S157. http://dx.doi.org/10.1079/BJN2002531. PMid:12088512.

Martinez-Gutierrez, F., Ratering, S., Juárez-Flores, B., Godinez-Hernandez, C., Geissler-Plaum, R., Prell, F., Zorn, H., Czermak, P., \& Schnell, S. (2017). Potential use of Agave salmiana as a prebiotic that stimulates the growth of probiotic bacteria. Lebensmittel-Wissenschaft + Technologie, 84, 151-159. http://dx.doi.org/10.1016/j.lwt.2017.05.044.

Meisel, H., \& Bockelmann, W. (1999). Bioactive peptides encrypted in milk proteins: proteolytic activation and thropho-functional properties. Antonie van Leeuwenhoek, 76(1-4), 207-215. http:// dx.doi.org/10.1023/A:1002063805780. PMid:10532380.

Moreno-Montoro, M., Olalla-Herrera, M., Rufián-Henares, J. Á., Martínez, R. G., Miralles, B., Bergillos, T., Navarro-Alarcón, M., \& Jauregi, P. (2017). Antioxidant, ACE-inhibitory and antimicrobial activity of fermented goat milk: activity and physicochemical property relationship of the peptide components. Food \& Function, 8(8), 2783-2791. http://dx.doi.org/10.1039/C7FO00666G. PMid:28702643.

Moslehishad, M., Ehsani, M. R., Salami, M., Mirdamadi, S., Ezzatpanah, H., Naslaji, A. N., \& Moosavi-Movahedi, A. A. (2013). The comparative assessment of ACE-inhibitory and antioxidant activities of peptide fraction obtained from fermented camel and bovine milk by Lactobacillus rhamnosus PTCC 1637. International Dairy Journal, 29(2), 82-87. http://dx.doi.org/10.1016/j.idairyj.2012.10.015.

Nematollahi, A., Sohrabvandi, S., Mortazavian, A. M., \& Jazaeri, S. (2016). Viability of probiotic bacteria and some chemical and sensory characteristics in cornelian cherry juice during cold storage. Electronic Journal of Biotechnology, 21, 49-53. http://dx.doi. org/10.1016/j.ejbt.2016.03.001.

Nielsen, S. M., Martinussen, T., Flambard, B., Sorensen, I. K., \& Otte, J. (2009). Peptide profiles and angiotensin-I-converting enzyme inhibitory activity of fermented milk products: effect of bacterial strain, fermentation $\mathrm{pH}$, and storage time. International Dairy Journal, 19(3), 155-165. http://dx.doi.org/10.1016/j.idairyj.2008.10.003.

Nighswonger, B. D., Brashears, M. M., \& Gilliland, S. E. (1996). Viability of Lactobacillus acidophilus and Lactobacillus casei in fermented milk products during refrigerated storage. Journal of Dairy Science, 79(2), 212-219. http://dx.doi.org/10.3168/jds.S0022-0302(96)763531. PMid:8708082.

Palaria, A., Johnson-Kanda, I., \& O'Sullivan, J. (2011). Effect of a Symbiotic Yogurt on Levels of Fecal Bifidobacteria, Clostridia, and Enterobacteria. Applied and Environmental Microbiology, 78(4), 933-940. http://dx.doi.org/10.1128/AEM.05848-11. PMid:22101054.

Ramchandran, L., \& Shah, N. P. (2008). Effect of versagel ${ }^{\circledR}$ on the growth and metabolic activities of selected lactic acid bacteria. Journal of Food Science, 73(1), 21-26. http://dx.doi.org/10.1111/j.17503841.2007.00577.x. PMid:18211357.

Rybka, S., \& Kailasapathy, K. (1995). The survival of culture bacteria in fresh and freeze-dried AB yogurts. Australian Journal of Dairy Technology, 50, 52-56.

Saarela, M., Mogensen, G., Fondén, R., Mättö, J., \& Mattila-Sandholm, M. (2000). Probiotic bacteria: safety, functional and technological properties. Journal of Biotechnology, 84(3), 197-215. http://dx.doi. org/10.1016/S0168-1656(00)00375-8. PMid:11164262.

Sadaghdar, Y., Mortazavian, M., \& Reza, M. E. (2012). Survival and activity of 5 Probiotic Lactobacilli strains in 2 types of Flavored Fermented Milk. Food Science and Biotechnology, 21(1), 151-157. http://dx.doi.org/10.1007/s10068-012-0019-z.

Sánchez, B., Delgado, S., Blanco-Miguez, A., Lourenco, A., Gueimonde, M., \& Margolles, A. (2017). Probiotics, gut microbiota and their influence on host health and disease. Molecular Nutrition \& Food Research, 61(1), 1-15. http://dx.doi.org/10.1002/mnfr.201600240. PMid:27500859.

Santillán-Urquiza, E., Mendez-Rojas, M. A., \& Vélez-Ruiz, F. (2014). Productos Lácteos funcionales, fortificados y beneficios en la salud humana. Temas Selectos de Ingeniería de Alimentos, 8(1), 5-14.

Sebastián-Domingo, J. J. (2017). Review of the role of probiotics in gastrointestinal diseases in adults. Gastroenterologia y Hepatologia, 40(6), 417-429. http://dx.doi.org/10.1016/j.gastrohep. PMid:28185664.

Senok, C. A., Ismaeel, Y. A., \& Botta, G. A. (2005). Probiotics: facts and myths. Clinical Microbiology and Infection, 11(12), 958-966. http:// dx.doi.org/10.1111/j.1469-0691.2005.01228.x. PMid:16307549.

Shi, J., Luo, Y., Xiao, Y., Li, Z., Xu, Q., \& Yao, M. (2014). Effects of fermentation by Lactobacillus casei on the antigenicity and allergenicity of four bovine milk proteins. International Dairy Journal, 35(1), 75-80. http://dx.doi.org/10.1016/j.idairyj.2013.10.010.

Souza, O. R. P., Perefo, P., Oliveira, M. N., \& Converti, A. (2012). Effect of inulin on the growth and metabolism of a probiotic strain of Lactobacillus rhamnosus in co-culture with Streptococcus thermophilus. 
Food Science and Technology (Campinas), 47, 358-363. http://dx.doi. org/10.1016/j.lwt.2012.01.031.

Vasiljevic, T., \& Shah, N. P. (2008). Probiotics-from Metchnikoff to bioactives. International Dairy Journal, 18(7), 714-728. http://dx.doi. org/10.1016/j.idairyj.2008.03.004.

Vinderola, C. G., Bailo, N., \& Reinheimer, J. A. (2000). Survival of probiotic microflora in argentinian yogurts during refrigerated storage. Food Research International, 33(2), 97-102. http://dx.doi. org/10.1016/S0963-9969(00)00011-9.

Willems, J. L., \& Low, N. H. (2012). Major carbohydrate, polyol, and oligosaccharide profiles of agave syrup. Application of this data to authenticity analysis. Journal of Agricultural and Food Chemistry, 60(35), 8745-8754. http://dx.doi.org/10.1021/jf3027342. PMid:22909406. 